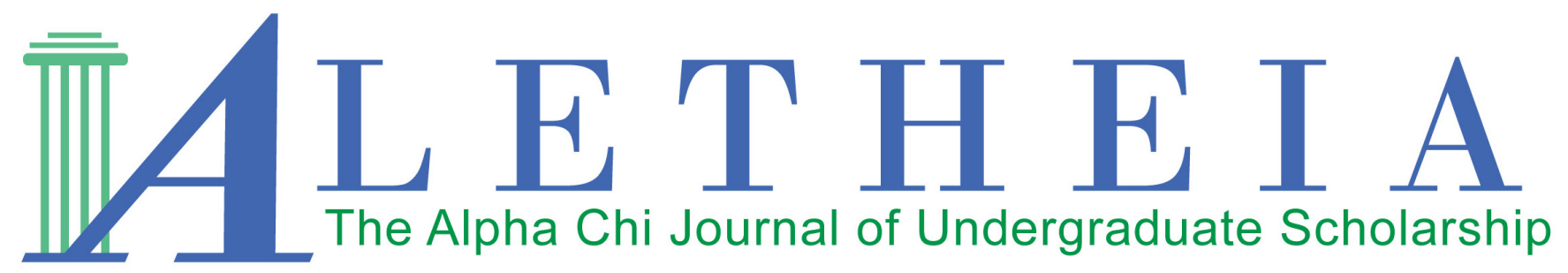

Volume 2 | Issue 2 | 2017

\title{
On Winged Words: An examination of the use of language in The Iliad to create and access the poetic space
}

\author{
Micole Gauvin \\ Carthage College \\ Wisconsin Delta Chapter
}

Vol. 2(2), 2017

Article Title: On Winged Words: An examination of the use of language in The Iliad to create and access the poetic space

DOI: $10.21081 / \mathrm{AX} 0121$

ISSN: 2381-800X

Key Words: poetry, Iliad, language, purpose, poetic, space

This work is licensed under a Creative Commons Attribution 4.0 International License.

Author contact information is available from the Editor at editor@alphachihonor.org.

\section{Aletheia-The Alpha Chi Journal of Undergraduate Scholarship}

- This publication is an online, peer-reviewed, interdisciplinary undergraduate journal, whose mission is to promote high quality research and scholarship among undergraduates by showcasing exemplary work.

- Submissions can be in any basic or applied field of study, including the physical and life sciences, the social sciences, the humanities, education, engineering, and the arts.

- Publication in Aletheia will recognize students who excel academically and foster mentor/mentee relationships between faculty and students.

- In keeping with the strong tradition of student involvement in all levels of Alpha Chi, the journal will also provide a forum for students to become actively involved in the writing, peer review, and publication process.

- More information and instructions for authors is available under the publications tab at www.AlphaChiHonor.org. Questions to the editor may be directed to editor@alphachihonor.org.

\footnotetext{
Alpha Chi is a national college honor society that admits students from all academic disciplines, with membership limited to the top 10 percent of an institution's juniors, seniors, and graduate students. Invitation to membership comes only through an institutional chapter. A college seeking a chapter must grant baccalaureate degrees and be regionally accredited. Some 300 chapters, located in almost every state, induct approximately 12,000 members annually. Alpha Chi members have been "making scholarship effective for good" since 1922.
} 


\title{
On Winged Words: An examination of the use of language in The Iliad to create and access the poetic space
}

\section{Micole Gauvin}

\author{
Carthage College \\ Wisconsin Delta Chapter
}

\begin{abstract}
This paper looks closely at the poetic language of The Iliad. The scope of this examination will be to take the conventional sense of poetry a step further to examine its connection to the soul in conjunction with the poet's ability to use language and other poetic gestures to create the poetic space. In this paper, this researcher posits that the poetic space is a psychological place-for, of, and in the soul. It is unlocked by poetic language; once there, the reader (adventurer) can see and interact with the events and people of poetry throughout the years. Specifically, this paper includes close-readings with careful studies of: the proem; characters' speeches and actions; similes and other such figurative language. Each of these studies of the language of the poem yields evidence of the poetic space and reveals a common thread tied to epistemology. Poetry is a result of experiencing truth. The poetic space informs knowledge and how we come to know it. In this investigation, it becomes evident that poetic moments, the soul, and truth all inextricably link. The closer we, the readers, look at the poetic language of The Iliad, the wider the door to the poetic space opens. All that is left is to enter.
\end{abstract}

Key words: poetry, Iliad, language, purpose, poetic, space

\section{Introduction}

For years, The Iliad has been the center of much scholarly attention and debate, not the least of which is the controversy that shrouds the identity of its mysterious author(s). While I acknowledge the "Homeric Question," a full consideration of the complexity of this debate will not be explored within the scope of this present project. For the chief concern of this paper regards the question of poetry itself and the ways in which the poet subtly yet powerfully manipulates the qualities of language to paint pictures both grand and grotesquemoments that transcend time, space, and pre-conceived notions. Moreover, even the understanding of The Ili$a d$ as an evolving text compiled of stock phrases and including contributions from many poets would only further ground and underline my assertion of the poetic space.

Indeed, as Richard Martin points out concerning the creation of The Iliad, "individual genius is not required... the genius of Homeric poetry is the powerful and flexible imaginative conception that keeps renewing itself through generations of performers and audiences" (42). It is this conception and its continued renewal contained and created in the language of the poem - which we deem the poetic space - that serves as the focus of this meditation on The Iliad. The process of this research focuses on the art of The Iliad itself and includes examinations of poetic moments, language, and gestures in order to demarcate a poetic space wherein readers across borders and time can enter into this communion of the art of language. 
This poetic space is the most critical and crucial aspect of poetry, for it is the place in which we witness and can create poetic moments. Poetry, poesis, means "to make." The poetic space is precisely what is made. It is a place in and of the mind where the reader has access to the insights of the poet and the poem's figures - to the truths $\mathrm{we}^{1}$ see embedded in their poetic moments. It is where we realize our own capacity for poetry and can respond in kind. Poets create this space by elevating and refining their language as well as the images they evoke so that readers can enter, experience, and see the truthexperience the beauty-hidden within the poem's language.

A final clarification on the text of choice as this study is so deeply grounded in its language: It comes with the territory of working in translated texts. By nature of translation, readers are removed a certain degree from the original words and intentions of the poet. However, we can move forward in confidence to examine this poem knowing that the essence of the poet's words carries through in the translation used for this study, which is Richard Lattimore's highly respected 1951 translation.

\section{Redefining Poetry}

The nature of this journey through The Iliad is centrally focused upon the poetic; it is therefore necessary to begin by clearly delineating the definition of poetry and how the understanding of poetry in this study goes even further beyond the conventional definition. Poetry is typically thought of as a form of art (usually in the medium of language, though not necessarily restricted to words alone) that showcases beauty. The poet must be ingenuitive and creative in building poetry. Poetry is often revealed in imaginative, creative, expressive, intense, stylistic, and/or emotional ways. The poetic, then, is everything that comes from or is related to poetrynamely, imaginative or creative literature. It is all that has "the style or character proper to poetry as a fine art"; it is all that is "elevated or sublime in expression" ("Poetic, adj.").

$1 \quad$ Here and after, the word we shall generally be used as an indicator of inclusiveness. This researcher invites the reader of the paper and readers of The Iliad to become a part of the investigation, engaging with the text, the poet, and the other readers across space and time.
And, as Jorge Luis Borges' posits concerning the art of poetry:

nowadays when we speak of a poet, we think only of the utterer of such lyric, birdlike notes as "With ships the sea was sprinkled far and nigh, / Like stars in heaven," [Wordsworth] or "Music to hear, why hear'st though music sadly? / Sweets with sweets war not, joy delights in joy" [Shakespeare]. (62)

With this perception, observers might readily identify The Iliad as a work of poetry and its author a poet based solely on its moments of pleasant verse. They might accurately highlight the Homeric similes and other examples of figurative language as poetic, instances in the epic that add emotion or intensity to the story playing out on the pages. However, this more conventional definition has its limits. Embarking on this study, we therefore refine this lens of thinking, taking cues from Percy Bysshe Shelley and how he defines poetry in his "Defence of Poetry," a work in which he often referenced the cornerstone of Western Literature, The Iliad.

\section{Enter: the 'soul'}

The most important element in this especial understanding of poetry that the conventional definition lacks is poetry's connection with the soul and a person's character.

Perhaps any mention of the soul outside of a traditional religious framework may appear misplaced in such a literary examination. However, in this adventure through the text, space exists even here for the indefinable and intangible aspects of thinking - not just understanding, but feeling and participating in poetry. As humans are integrated beings, it is possible to enter and experience poetry as well as poetry's power to transcend space and time by entering into the poetic space.

The Iliad takes the conventional classification of poetry even further-beyond emotion, beyond figurative language. It really zeroes in on the motivating factors that lie behind the exhibited poetic language and actions. In this examination of the text, the typical conventions of poetry are used to help identify instances of heightened poetic feelings. To be more precise, moments of poetry in the text (also classified as poetic moments, gestures, or language) are sought out and examined; these moments include anything the audience experiences by seeing, hearing, or feeling, which the poet or figures in 
the poem create by speaking, singing, weaving, crafting, acting, and so forth. Nearly every example of figurative language, elevated and sublime expression, or otherwise intense and expressive ideas are thereby indicators of poetry.

In addition, Shelley's redefinition of poetry is crucial to understanding the depth of poetry at work in this examination. Poetry is experienced as "the expression of the imagination" (Shelley 149). Poetic momentsthese expressions - become both the object and the poet's apprehension of it combined, resulting in something entirely new. Ultimately, as will be revealed, "poetry turns all things to loveliness" (Shelley 72). Thus, the poetic is that which distorts order and orders chaos, reveals hidden beauty and exposes false claims of beauty, speaks to the truth that is seen, and sees the truth in what is spoken. In the images they create, these poetic moments of the poem - ironic, bold, figurative, challenging, etc. - all contain a power that sets them apart from the ordinary moments. These are the moments that become the foundation for this investigation.

Next, this study will focus in on these poetic moments, taking them a step further to encompass every part of the complex and intricate picture. More specifically, this study considers who is exhibiting and who is inhabiting these poetic moments, how they are using the poetic conventions, when, where, and to whom they are speaking or acting in this distinctive manner, and, ultimately, why. To what end is that scene, piece of art, language, or action being elevated? Such a frame, such questions, arm this study as we stop merely reading and begin participating in the poem's pages. Continuing this close study of the text, a connection is uncovered linking a person's character with their capacity for poetry (that is, their propensity for seeing truth in conjunction with their resulting proficiency in wielding words in a heightened way). Further, this connection rests on the fact that poetry results from seeing truth. Moreover, these poetic moments and exhibitions of poetry seem to stem from a person's intrinsic poetic character and capacity.

In fact, the figures related to the epic (both bodies within the pages and those outside of it, reading the pages) are intrinsically poetic and have a (natural) capacity for poetry. Turning to the OED, there is evidence that by nature the word intrinsically looks within, defined as "internally, inwardly, within," and "by, or in relation to, the inner nature of the thing: in itself; inherently, essentially" ("Intrinsically"). Tying such an inward-driven word to poetry inevitably takes that word itself inward, revealing that poetic essence stems from within a person. This intrinsic capacity is demonstrated time and again in The Iliad by such characters as Hektor, Achilleus, and even Achilleus' horses. Truly, the ability to see, to hear, and ultimately to speak poetically, actually comes from within, and this leads to having a (natural) poetic capacity. Again looking to the OED, capacity is defined as the "ability to receive or contain; holding power" ("Capacity" ). This definition is a journey inward, towards the self, and now poetry is seen actually starting and ending within a person even though it sometimes manifests itself externally. Truly, man is the lyre upon which inner and outer forces create a melody; the soul within man responds to these forces and creates a harmony. Additionally, poetic moments are frequently born of or follow a time when the person in question experienced truth. The poetic capacity of a person, therefore, depends on their ability to take the truth they see with their eyes or the insight they gain via other means, internalize it, and then express it in a manner that aligns with the conventional sense of poetry.

With its very inwardly focused nature, poetry seems to penetrate more deeply than the mind or even the heart; it accesses something superior to mere intellect or raw emotion. In the sense that is accepted for this journey through The Iliad, poetry thereby bypasses these accepted poetic modes to enter the very soul; it becomes necessarily a part of those who hear, speak, or read it. Becoming so entwined with the soul, those partaking in poetry now possess pieces of the poetic space that enable them to unlock it for themselves, enter, and commune with other readers, characters, and the poet, within the context of the poem and even across centuries.

Indeed, poetry longs to be shared - it aches to feel the soul of another and give of its own. It takes ordinary understandings and raises them to new heights, pushing psychological boundaries, and revealing the philosophical mysteries of the poetic space.

Therefore, this inquiry leads into a realm that is more than a simple artform available to a few select, gifted artists; it does more than tell a sad story or paint a pretty picture. Poetry transcends the conventional definition to unlock and reveal a part of the soul and mind that are not immediately grasped. The poetic elevates more than just the language, but the very speaker. It necessitates a second glance, a deeper look to see the beauty that is not always immediately on the surface, but which neverthe- 
less speaks to our souls. Moreover, this idea of poetry's inward-driven nature, connection to the soul, and root in seeing truth makes the theme of knowledge in the poem of especial concern. Sifting through the lines of The Iliad, there lies a common thread linking the poetic with seeing and realizing truth.

\section{Turning to the Text}

\section{Connecting our definition of poetry to close readings of parts of The Iliad}

Hitherto, this research has contemplated various components of poetry, how they might be used, and what they mean in each case. But what exactly does The Iliad itself say about poetry? Recognizing the capacities of the poetic space, these deeper meanings are unearthedmeanings that before lay just out of reach beneath the surface of ordinary and untested understandings. In his manipulation and command of language throughout The Iliad, the poet invites readers-thinkers into the poetic space. Upon entering, the poet reveals its various components. Once curious readers have been so gifted with the key to unlocking this sphere, they can access it on their own without relying on the gods or any other power, for their souls will be irrevocably tied to the poetic space and carry with them a piece of its power. Possessing now this key, we as curious readers-thinkers embark on this study in earnest by tuning ears to hear the voices of the poet and the cries of the characters of the poem, training eyes to examine the patterns of poetry in their language. Now, this study shifts to examine a few instances of seemingly strange but powerful beauty in the poem and then moves on to a brief but careful overview of the speeches of divine, semi-divine, mortal, and other figures before finally centering on the varying types and forms of language used throughout the poem (for example, similes). In all of these forms and examinations of language, there is a common thread tied to epistemology, revealing something about how knowledge is unlocked and secured. It is in this discussion of the poetic space that we find poetic language, the soul, knowledge, and how we can possibly know it, all inextricably linked.

\section{A peek at the Proem}

In the opening lines, the poet invokes the Muse, commanding her:
Sing, goddess, the anger of Peleus' son Achilleus And its devastation, which put pains thousandfold upon the Achaians,

Hurled in their multitudes to the house of Hades strong souls

of heroes, but gave their bodies to be the delicate feasting

of dogs, of all birds, and the will of Zeus was accomplished

since that time when first there stood in division of conflict

Atreus' son the lord of men and brilliant Achilleus.

(Pg\#; bk 1. 1-7)

On the surface, this invocation appears to be merely about Achilleus' anger. However, looking deeper, these words actually reflect the poet's mastery in wielding language. In fact, a poetic space here begins to emerge in The Iliad that bridges the divide between the mortal and immortal realms. Immediately, in the first line of the epic there is an example of this merging of worlds. Achilleus is the son of Peleus, a mortal, and of Thetis, a goddess. As a member of the race of heroes, Achilleus is the very embodiment of the type of union and duality this study is concerned with when considering the nature of the poetic space. Similarly, The Iliad itself can be thought of as a sort of semi-divine, heroic offspring of the poet, a mortal, and the goddess named in the proem (presumably the Muse); amidst the complexities of the poet's paradoxical commanding and invoking of the Muse, we see a partnership, the product of which is the poem at large. Because the poet says, "Sing, goddess" in the opening line of the poem, it follows that the developing poem is infused with the voices and influences of both the poet and Muse (Iliad, I, 1). Aligning this idea with the previously proposed illustration, the poet and Muse are then the parents, and the resulting poem of their shared collaboration and performance is their offspring. The lifeblood of the poem is in its words and there exists language both mortal and immortal throughout the poem. Therefore, in the proem, both Achilleus and the poem are established as examples of the merging of divine and mortal realms.

Recalling the initial definitions of poetry and the poetic space given at the onset of this paper, I am claiming that this poetic space is psychological - a place for and in the soul. It is a place which we cannot reach in our everyday life. Existing as it does beyond the confines 
of ordinary language, it can only be reached through poetic language. This poetic language is at once higher, elevated above the everyday as well as the gods. It is the key to unlocking this intermediary sphere that is the poetic space. Seeking a concrete example of the abstract ideas and definitions explored earlier, we find a seemingly simple example of the type of language that can be classified as poetic and that helps define the poetic space residing in the epithets present in the first and last lines of the proem. The poet names "Peleus' son Achilleus" (Iliad, I, 1) "Atreus' son the lord of men" (Agamemnon), and "brilliant Achilleus" (Iliad, I, 7). These epithets intimate a special knowledge that can only be accessed in the poetic space.

Additionally, there is found strong language that evokes the imagination and constructs the poetic space in the midst of the proem as the poet paints the devastation of Achilleus' anger and how it "hurled in their multitudes to the house of Hades strong souls / of heroes, but gave their bodies to be the delicate feasting / of dogs, of all birds" (Iliad, I, 3-5). The rich imagery of these words does more than paint a picture of the pain of the Achaians; it goes further to reach a part of our souls, making us (the readers-observers-thinkers) feel a part of their pain as we read, hear, and internalize the language. We feel pain at this image because of the careful contrasting of the word heroes and the image of their bodies being not just sent, but hurled forcefully, mercilessly, wastefully down to Hades. There exists a certain positive connotation in the word heroes that echoes admiration and endearment. Though they are still unknown, they seem much closer. At the very least, the word heroes heralds that these men are believably heroic, whatever their faults. Thus, there is pain in losing them (and so suddenly at that). This pain is compounded when we learn of the indignity that follows their deaths, namely, their bodies becoming bird fodder. The critical choice of words - laden with connotations that reach out and attach the lives of their carriers to our own - as well as their careful order impose a sort of bias: news of the heroes' deaths precedes any knowledge of their deeds which would be used to judge whether or not their deaths were just. Such is the poetic space at work, sharing knowledge and emotions through language in a psychological dimension that unlocks parts of the soul. The proem contains manifestations of the merging of two worlds, masterful examples of epithets, rich imagery that highlights and evokes pain amidst other emotions, enhancing understanding of the poetic space.

\section{Other poetic moments, images, and gestures}

The next passage of poetic prominence to be considered is the image the poet gives of how "the corpse fires burned everywhere and did not stop burning" (Iliad I, 52). The image is a strong one, and supports Shelley's claim that poetry "turns all things to loveliness," even corpse fires (72). It is worth pausing here to qualify what exactly is meant by loveliness, for the idea that corpse fires continually burning are lovely may be a bit discomfiting at first glance. This present pause is not the first quest to understanding the strange loveliness that exists in such intense images; indeed, the paradoxical pleasure humans seem to derive from looking at apparently morbid representations is a topic that can be traced back to Aristotle. In his Poetics can be found similar curiosity and help in understanding why "we delight in contemplating the most accurately made images of the very things that are painful for us to see, such as the forms of the most contemptible insects and of dead bodies," why we can look at the corpse fires continually burning and deem it a moment of poetry, of loveliness (Aristotle 22). As Aristotle answers the inquiry:

what is responsible even for this is that understanding is the most pleasant not only for philosophers but in a similar way for everyone else...They delight in seeing images for this reason: because understanding and reasoning out what each thing is results when they contemplate them. (22-23)

We as humans long to understand; we thirst for knowledge. In reading these horrifying but poetic words, our souls reach out for a hint of recognition in these images and representations, even of pain, of something dark that cannot be fully acknowledged in reality. In the poetic space our souls have a chance to look without blinders at all the pain and pleasure of distorted realities; there is a chance to share the pain contained within and respond properly to the pain without of the departed who may not have necessarily received their due. In the moment of the corpse fires actually burning, it would be natural to turn away, and the souls in the fire would be abandoned and forgotten; but in the image that the poet presents of the fires in word form, we can pause to look, to feel, to mourn, to share. The human need to see representation of what we cannot face in reality and the need to connect are a part of what make corpse fires lovely. 
And so, poetry presents images and representations to direct readers-thinkers towards the truth that we need to see. Indeed, a poem "is the very image of life expressed in its eternal truth" (Shelley 54). Poetry is the "mirror which makes beautiful that which is distorted" (Shelley 54). Truly, it is the mirror by which the most hideous death is reflected into something better, by which corpse fires are made lovely. Looking at it through this poetic lens, we readers are able to experience it outside of our limited understanding in hope that we might come closer to these eternal truths. "Poetry thus makes immortal all that is best and most beautiful in the world," and these truths are realized in the poetic space so that they, at last, are able to be confronted in the form of the representations which the poet constructs (Shelley 73). "Poetry redeems from decay the visitations of the divinity in man" (Shelley 73). Though disguised in the vices, manipulations, and faults of its characters, the beauty of the eternal truths of the invisible world of mankind cannot forever be hidden and is at the core of poetry, reflected fully in the creation of the poetic space. Indeed, just as Aristotle and Shelley have seen, "Poetry turns all things to loveliness," even corpse fires.

Admittedly, the next example of poetic language does not present itself as such on the surface; but as Shelley explains, the darkest of vices cannot forever hide, only temporarily disguise the beauty that lies within. Such is the case in this next piece of language. Having relinquished (if only momentarily) the physicality of his anger, Achilleus relies on the allowance made by Athene that he is able to abuse Agamemnon with his words. The result is this insult, which is posited here as another example of the poetic space. Achilleus calls Agamemnon a "wine sack, with a dog's eye, with a deer's heart" (Iliad, I, 225). At first glance, it might be easy to readily dismiss this language for its ugliness, but look closer at the impetus and the origins of these words to see that they spring from something more divine and contain something far nobler than an ordinary insult might carry. These words denote the higher road Achilleus must take when Athene stays his menos in the midst of his immense achos. They are his release right now and show a careful choice being made. Furthermore, they are spoken at the behest of a goddess. In this way, the poet turns all, even seemingly ugly language, into loveliness, making beautiful what is distorted so that not only is this insult poetic, but the distorted feelings of Achilleus as he confronts and wrestles with his rage are given vent in a nobler way. This is perhaps a different aspect of the poetic space that is a bit unexpected. Understanding this other, even darker side of poetry reveals another dimension of the poetic space. It enables a more full and rich experience of the deeper, truer sense of poetry.

\section{Poetic moments and seeing truth}

The more time spent in and with the text, the more it becomes evident that while language is a crucial part of the poetic space, there is more involved in what constitutes the poetic. In all of the instances of the language of the gods and humans in the poem, it becomes increasingly apparent that language alone does not create the poetic space. Underlying the poetic sphere is the character of those speaking more than their actual language. Indeed, it seems that in The Iliad, human or divine character is intrinsically poetic; and moreover, this capacity for poetry (or poetic character) is integrally connected with seeing the truth. There appears to be a natural capacity for poetry in the poet as well as in certain mortal and immortal characters. The mixed blood of the heroes (Achilleus, Sarpedon, and Helen) may be tied, in part, to their intrinsic poetic character. But above all else, the capacity for poetry has something to do with seeing truth. Consider the cases of Thetis, Zeus, Hera, Hephaistos, Sarpedon, Achilleus, Helen, the poet, Glaukos (with the "leaves of men" simile), and so on. Almost all of their poetic moments appear connected to knowing or seeing truth.

Thetis' poetic character is integrally connected to her intuition about knowing; she needs to see Achilleus retell his pain so that they both (as well as the reader) may truly know it. Zeus' poetic moments of silence along with his thunderous, Olympos-shaking nod are so powerful because he knows and foresees the truth of what they ultimately mean: namely, the deaths of thousands amidst great turmoil among the Achaians, Trojans, and gods. This turmoil is what Hephaistos sees as the truth of what the gods' meddling in mortal affairs will bring about; his poetic gestures of craftsmanship with the houses of the gods, the shield of Achilleus, and the comedic act of serving the other gods are all in response to that knowledge; additionally, his craftsmanship on the shield serves a twofold purpose in that it reveals the truth he sees in such a way that lets readers see the truth, too (Iliad, I, 573-583). Hera sees the interaction between Zeus and Thetis - which is where her challenging/defiant/Helen-like language stems from - in response to the 
truth she sees. Sarpedon sees the truth of the heroic code, the reason why they are fighting and why they cannot back down; he reveals this in his language. Achilleus, too, on some level sees the truth in his anger, his mortality, and in his power struggle with Agamemnon; furthermore, as he sees the truth of his anger and his desires more clearly, the poetry of his language and gestures evolves to fill completely his intrinsic poetic character. Helen sees the truth of her situation, her helplessness, and her language conveys her lamentations; she sees the truth of the fighting between the Trojans and Achaians and weaves it into her robe; she sees the truth of her powerlessness as she succumbs to the manipulations of the goddess. Glaukos reveals the truth he sees in their fighting and in the xenia that can survive even the horrors of war as he waxes poetic with his simile that paints the hidden parallel between men and leaves: the young grow to replace the fallen elder generation.

\section{Even horses}

In light of this connection between poetic character and seeing truth, there is one more example (one last category of figures) that is especially moving and noteworthy and which stretches this capacity for poetry beyond humans and gods to include animals as well. In Book Seventeen, in the midst of the battle raging over Patroklos' body, the poet invites the reader to take special notice of the horses of Aiakides; indeed, he unveils their poetic capacity which surfaces in response to the truth they see. The scene revolves around the fallen body:

But the horses of Aiakides standing apart from the battle

wept, as they had done since they heard how their charioteer

had fallen in the dust at the hands of murderous Hektor.

In truth Automedon, the powerful son of Diores, hit them over and over again with the stroke of the flying

lash, or talked to them, sometimes entreating them, sometimes threatening.

They were unwilling to go back to the wide passage of Helle and the ships, or back into the fighting after the Achaians, but still as stands a grave monument which is set over the mounded tomb of a dead man or lady, they stood there holding motionless in its place the fair-wrought chariot, leaning their heads along the ground, and warm tears were running

earthward from underneath the lids of the mourning horses

who longed for their charioteer, while their bright manes were made dirty

as they streamed down either side of the yoke from under the yoke pad.

(Iliad, XVII, 426-440)

In this passage, even horses are endowed with and have the capacity for poetry. This truth is revealed in their poetic gestures: namely, their crying, mourning, and refusal to leave Patroklos' body, in addition to their very embodiment of his grave (Iliad, XVII, 434-435). This brief description of the horses is charged with emotion; the language is haunting, and the image painted of the mourning horses is striking. We feel the pain of the horses of Aikides as they weep and as they have been weeping for a very long time since Patroklos first fell. The description of how they are not willing to move is extensive (Iliad, XVII, 432-433). The poet's words here cross the Helle and back to the fighting Achaians, unlike the horses they describe. Then there is the elaborate simile likening the horses to a grave. In a battle where many fallen soldiers are left unburied, unmourned, to be the dinner of birds and dogs, these horses of Aiakides want to make sure their master is not among the forgotten animal fodder; so, they stand as his grave, themselves a living, breathing, ever-mourning testament to their beloved charioteer. Standing motionless by Patroklos' body, they are his tomb, his grave monument. Their weeping serves as a remembrance of Patroklos' life, his bravery. Their weeping serves also as a reminder to those left behind, those witnessing this scene on the battlefield, those reading it now, immortalized as these actions are by the poet's words. For in the midst of a war, these horses take the time to pause, to grieve, to remember. This, then, is the essence of poetry.

Furthermore, we see that this remarkable response and revelation of poetic character in the horses is also tied to seeing truth. The immortal horses have seen their 
beloved and mortal charioteer fall before their very eyes; then, they were helpless to save him, and now they are helpless to move on. Therefore, their poetic gestures here result from the truth they have just witnessed: the death of their beloved Patroklos. Additionally, they see him fallen, stripped of his armor, caught in a tug-of-war between the two warring sides, and they know the man they loved is being apparently forgotten-going unmourned, even if only momentarily - and that he will not soon enough have the grave or burial he deserves. To help compensate for this lack, for this truth that they see, the horses assume the responsibility of mourning and refuse to move, becoming the grave. Their poetic gestures are their response to seeing truth, further supporting the central argument that seeing truth is somehow a stepping-stone to poetic moments and gestures. Tracing these moments of seeing truth and instances of poetic gestures, we follow a path that intertwines and connects the poets within the pages of The Iliad to each other as well as to the reader. It is important that seeing truth leads to poetry and that the ability to see it marks one for the poetic; it grounds poetry in truth and makes something that could seem on the surface to be quite elusive and ethereal actually quite real and attainable.

One last matter of note in this passage, Automedon is unable to move the horses or redirect them, either into the fighting or out. If we recall that "Automedon" is the "pilot of the self," the reason for his inability to drive the chariot takes on a new meaning. Having lost Patroklos, his charioteer, Automedon has lost a 'self' to pilot; therefore, he, like the horses, is at a loss for how to move forward. And this truth witnessed in both the steadfastness of the horses and the immobilizing/crippling of Automedon and his ability as a chariot-driver that the poet highlights for us now in the poetic space, is a truth that reaches far beyond the pages, beyond this scene, and into our very hearts. The losses suffered in this war (in any war), though they may be mentioned only in passing on the page or breezed over in the retelling, are not suffered lightly. True loss as is suffered by the members of this scene is debilitating, especially when it involves a loss of self and/or a loss of purpose. That is why the poetic gestures of the horses and the poetic language used by the poet to describe this scene are so powerful, so perfect. They reveal truth - a truth not easily defined but one that is surely felt. We as the readers-thinkers-observers now also mourn Patroklos, not just because he was good and died when he should not have, but because we see the horses mourning, and we recognize their grief is a mirror to our own. These poetic words awaken these feelings inside and cause a moment of pause over these words because they are poetic. Moreover, we pause because we, like the horses and like Automedon, are unable to move on. In the midst of war, the poem allows a pause; we take the time we do not necessarily have to mourn Patroklos and the loss of our selves. Thus the poet sees the truth in all of this, uses it to create the poetic space, invites the reader-thinker in, and then reveals a truth that reaches our very cores. The case of the horses undeniably underscores the connection between an intrinsic poetic capacity and seeing truth.

\section{Apollo's simile}

Stepping back now, it is important to look at one of the most distinct and magnificent ways in which the poetic space manifests itself, that is, in the poet's construction and implementation of Homeric similes. These forms of figurative language are woven quite frequently into The Iliad. Often, these similes introduce an image of peace amidst the tumultuous and ghastly war scenes. In other instances a comparison is drawn between two most unlikely candidates. In ordinary life, the comparison would not make sense; but in the poetic space where the poet lives and wherein he is inviting readers-thinkers to participate, these comparisons not only somehow make sense, but they finally and fully explain that missing piece, describing the true essence of something that was lacking because the ordinary description was never quite right. Admittedly, the chosen simile is not necessarily among the greatest of Homeric similes. Nevertheless, it is worthy of consideration. It is as if, in the first book, the poet is warming up, starting out slowly, disclosing first what a simile is before revealing his mastery in manipulating language and extending these similes into the splendid images that are created in later books.

The principles of close reading emphasize the importance of order, and so this research focuses first on that which is first. Note that in the passage describing the conflict between Agamemnon and Apollo's priest (which was referenced earlier), the first simile of The Iliad is brief but powerful as it breathes again of the poet defying expectations and reveals language that is poetic, effectively demarcating the poetic space. In the midst of his anger and the clashing of his silver bow, Apollo, 
god of the sun, "came as the night comes" (Iliad, I, 47). Fleeting as it is, this simile is nonetheless quite compelling as it defies our expectations of the sun god, the god of sight, giving us an entirely unexpected comparison of two things utterly opposed to each other (light and the very absence of it). Even still, somehow in this poetic space, the simile endows Apollo with more power and more brilliance than all the power of daylight.

When the actual coming of night is examined more closely, it seems night is wrapped up in a bit of a paradox, for it comes slowly and then all at once. The light fades, dims, even changes colors, and then all of a sudden there is blackness punctured first by one glimmering star, then another, and then a multitude, setting the sky ablaze. This changing reflects the actions and feelings of Apollo who brews in his anger, clashing his silver bow, maybe dimming in the brightness of his divinity as anger takes hold and darkness descends; it is a slow build up to the assault; and then all at once, the sun disappears and the god of the sun that is no longer there lets loose an arrow and the attack begins in earnest as he has come as the night comes. Returning to the image of night, the suns disappear under the horizon, replaced by the black sky, moon, and stars. In this simile, the poet inserts the sun in a scene where it does not belong, painting a picture of night with a dark brushstroke that includes all the brightness of the sun.

But it is not just in the simile itself that the poet casts Apollo in this shade of night. For surrounding the simile of Apollo coming as the night comes, the poet also extends the image in his description of Apollo unleashing his reign of terror; his developing actions mirror the progression of night. Just as night comes slowly, dimming gradually and then suddenly dark, so, too, Apollo advances. For, after the priest of Apollo speaks his prayer, "Phoibos Apollo heard him, and strode down along the pinnacles of Olympos, angered in his heart" (Iliad, I, 43-45). Here we see Apollo striding slowly, perhaps picking up speed gradually, as his color dims to match the anger in his heart. What is noticed first is the sight of the god: he is "carrying across his shoulders the bow and the hooded quiver; and the shafts clashed on the shoulders of the god walking angrily," and now then follows sound directly after (Iliad, I, 45-47, 76). It is a slow build in anger as Apollo approaches, coming "as night comes down," but then all of a sudden he is there and it is dark; for he "knelt then, / apart and opposite the ships and let go an arrow" (Iliad, I, 47-48, 76). It is noteworthy to mark the particular use of 'an arrow.' The singularity of the lone arrow that Apollo lets fly is like the first drop of rain in a storm or the first piercing star in the night sky.

Further, his ensuing attack progresses in the same way that night does, slowly, steadily, and then suddenly: "Terrible was the clash that rose from the bow of silver." Here the poet increases the volume of the scene and next paints the picture: "First he went after the mules and the circling hounds, then let go / a tearing arrow against the men themselves and struck them." With one arrow, suddenly is realized all the pain and terror - the night of Apollo has fully descended. The scene intensifies, visually, audibly, and now with the introduction of scent: "the corpse fires burned everywhere and did not stop burning" (Iliad, I, 49-52, 76).

Continuing, the poet extends the simile to mimic the coming of night as we see first one arrow hitting one victim and we feel his pain; then, all of a sudden, there are corpses so many that fires are needed to try to ward off the night. But just as there is no escaping the night, there is no escaping Apollo's terror until it is complete - until the light of dawn shows at long last.

Hence, in this example, the poet paints a dark and different portrait of Apollo. As he extends the simile of the night, the readers-thinkers observe the full development of his anger, progressing in the same manner of night, and laying hold of the Achaians just as strongly and steadfastly as the darkness. In all of this, the god of the sun is shadowed in a new light (or lack thereof). In the poetic space, gods appear crossing over into the mortal world, changing their forms and departing from their typical roles; the god of the sun becomes night itself when he comes to unleash his wrath on the Achaians. In this simile, the poet paints a picture of Apollo's power and reveals an unexpected and even dark change in the god. The poet seems completely conscious of his word choice, this particular picking and placing of a simile. In the opening book, then, is found the first budding fruit of the poetic space as the poet introduces his first Homeric simile.

\section{That epistemological thread}

Thus, it appears that running through all of these concerns relating to language and the poetic space in the context of The Iliad is a common thread tied closely to the theme of epistemology. According to the OED, epistemology is defined as, 
the theory of knowledge and understanding, esp. with regard to its methods, validity, and scope, and the distinction between justified belief and opinion; (as a count noun) a particular theory of knowledge and understanding. ("Epistemology")

The idea of knowledge and how we know it underlies each of the points discussed in these pages. Returning to the text once more to conduct an explicitly epistemological journey through the epic, this next close reading focuses on the intricacies of knowledge revealed in Thetis' and Achilleus' first interaction compared with disparities in knowledge between members of the epic in Achilleus' and Agamemnon's feud. Finally, we look at the privileged viewing and conspiracy-like insight that we the readers share with the poet as we are elevated above the status of mere mortals. For in this passage, Thetis also speaks to that trait of knowledge that is different and special. This notion of sight informing knowledge unfolds further as she asks Achilleus to tell her about what happened so that they shall "both know" even though they both already know. Moreover, this first interaction between mother and son along with her insistence on hearing his sad tale repeated, echoes Jenny Strauss Clay's ideas regarding eidenai; more specifically, divine eidenai is above mortal eidenai and knowledge gained through seeing is above knowledge gained through hearing. Thetis does not want to merely hear him tell it as in a prayer, but to see him tell it to her.

Thetis, as a god, is gifted with the ability to see from afar, so she already knows what Achilleus is angry about because she witnessed it actually happening to him. Because of this awareness, she is not merely asking him to repeat it to check his facts; rather, she needs to see him tell it once more to see his emotions, rage, all that is contained inside of him that does not come across in just words but which requires sight to know. Moreover, in having him repeat all the events she is helping ground his own knowledge of his anger and of his self. As he repeats it, he sees it all, knows it again more fully, and is more aware of the true nature of his feelings. In his retelling, we begin to see already a change in his feelings and his perception of what has happened to him, for he merely mentions Briseis, the apparent origin of his anger, in passing and not even directly by name. He says in the flow of his angry retelling that "even now the heralds went away from [his] shelter leading Briseis' daughter, whom the sons of the Achaians gave [him]"
(Iliad, I, 391-392). That is all the mention he makes of her, continuing on his supplication and launching then into his request for honor.

Side by side with Achilleus, the readers see the focus of his anger begin to change and morph into what we will see more fully in Book Nine when he speaks again. Seemingly a completely changed man, he voices the innermost truths of his heart, anger, and the poem, claiming:

Fate is the same for the man who holds back, the same if he fights hard.

We are all held in a single honor, the brave with the weaklings.

A man dies still if he has done nothing, as one who has done much.

Nothing is won for me, now that my heart has gone through its afflictions

in forever setting my life on the hazard of battle. (Iliad, IX, 318-322)

This disillusioning discovery that life is not fair and that fighting is futile is what lies at the heart of Achilleus' anger and is that from which he asks Thetis "to protect [her] own son" (Iliad, I, 393). When Thetis asks Achilleus to communicate again his frustrations and anger, this is what she sees; as he recreates his pain through his own words, this is what Achilleus begins to see; and as readers-thinkers are afforded the same view in the poetic space, this is what we see-a picture of pain that becomes clearer after Achilleus appears again in Book Nine. These two portraits of the hero lend depth and insight into his character as well as the theme of the poem. In the poetic space, the poet grants to the readers a privileged position that authorizes us to see and know things the mortals in the poem might not. There is a unique bond between the poet and audience, a bond strengthened and facilitated by eidenai. Moreover, the allure of the poetic space is entirely wrapped up in eidenai and the longing to not just know, but to see and know. After all, to see is to know and to know by seeing is far superior to knowing by mere hearsay.

\section{Conclusion}

We could continue to examine these examples of poetic language that permeate the entire epic, further demarcating the poetic space, deepening understanding 
of poetry and how it works both within and outside the pages of the poem. However, a more thorough investigation of The Iliad is beyond the scope of this present adventure. We leave off on such a focus study for now, letting these thoughts and ideas inform future reading of The Iliad (and all poetry).

In the opening lines of the proem, through the speeches of figures semi-divine, divine, and mortal and through the varying forms of language (including similes, metaphors, imagery, epithets, and so on), the poet carefully and consciously wields language to reveal the poetic space - an intermediary place between the divine and mortal realms wherein gods and humans interact, commune, access and experience truth, as well as create even more poetic moments.

Beginning with the bare definition of poetry, this study of The Iliad in conjunction with the work and ideas of countless thinkers writing in the centuries since this foundational Western text, attempts to enhance and refine our understanding of poetry. In this exploration, poetry's connection to the soul and its power to create the poetic space has been witnessed anew. Through all of these findings, this study underscores some learning about knowledge and how we can possibly attain it. On winged words we find the purpose of the poet in creating the poetic space in and through the pages of The Iliad. Such is the power of poetry as its origin in truth connects our minds to the minds of those who came, spoke, and thought before us, for it unlocks the truth and shares it within our very souls.

\section{Acknowledgement}

The author wishes to express her sincere appreciation to Dr. Seemee Ali for her guidance and support in making this research possible and helping to capture these winged words on paper.

\section{Works Cited:}

Aristotle. Poetics. Translated by Joe Sachs, Focus, 2006.

Borges, Jorge Luis. "The Telling of the Tale." Atlantic Monthly, vol. 286, no. 3, Sept. 2000, pp. 62-5.

"Capacity." Oxford English Dictionary Online, Oxford UP, 30 June 2014, www.oed.com.proxy.carthage.edu/view/ Entry/27368?redirectedFrom=capacity\#eid.

Clay, Jenny Straus. The Wrath of Athena, Princeton UP, 1983.

"Epistemology." Oxford English Dictionary Online, Oxford UP, 30 June 2014, www.oed.com.proxy.carthage.edu/ view/Entry/63546?redirectedFrom=epistemology\# eid.

Homer. The Iliad of Homer. Translated by Richard Lattimore, 1951, U Chicago P, 2011.

"Intrinsically." Oxford English Dictionary Online, Oxford UP, 30 June 2014,www.oed.com.proxy.carthage.edu/ view/Entry/98700?redirectedFrom=intrinsically.

Martin, Richard. Introduction. "Homeric Questions and Some Modern Answers," The Iliad of Homer. Translated by Richard Lattimore, 1951. U Chicago P, 2011.

"Poetic." Oxford English Dictionary Online, Oxford UP, 30 June 2014, www.oed.com.proxy.carthage.edu/view/Entry/146552? redirected From= poetry\#eid.

"Poetry." Oxford English Dictionary Online, Oxford UP, 30 June 2014, www.oed.com.proxy.carthage.edu/view/ Entry $/ 146532$ ?rskey $=$ LJ1HfJ\&result=1\&isAdvanced=false\#eid.

Shelley, Percy Bysshe. "A Defence of Poetry." 1820. Towards the Open Field: Poets on the Art of Poetry 18001950, edited by Melissa Kwasny, Wesleyan UP, 2004, pp. 48-76. 